\title{
Biological $P$ cycling is influenced by the form of $P$ fertilizer in an Oxisol
}

\author{
Andrew J. Margenot ${ }^{1,2} \cdot$ Rolf Sommer $^{3} \cdot$ John $_{\text {Mukalama }}{ }^{3}$ Sanjai J. Parikh ${ }^{2}$
}

Received: 11 November 2016 / Revised: 16 July 2017 / Accepted: 18 July 2017 / Published online: 11 August 2017

(C) The Author(s) 2017. This article is an open access publication

\begin{abstract}
Phosphate rock (PR) is an alternative fertilizer to increase the $\mathrm{P}$ content of P-deficient weathered soils. We evaluated the effects of fertilizer form on indicators of biological cycling of $\mathrm{P}$ using an on-farm trial on a Rhodic Kandiudox in western Kenya. Treatment plots were sampled after 13 cropping seasons of $\mathrm{P}$ applications as Minjingu phosphate rock (PR) or as triple super phosphate (TSP) $\left(50 \mathrm{~kg} \mathrm{P} \mathrm{ha}^{-1}\right.$ season $\left.^{-1}\right)$, as well as a P-unfertilized control $\left(0 \mathrm{~kg} \mathrm{P} \mathrm{ha}^{-1}\right.$ season $\left.^{-1}\right)$. Soils $(0-15$ and $15-30 \mathrm{~cm})$ were analyzed for microbial biomass $\mathrm{P}\left(\mathrm{P}_{\mathrm{mic}}\right)$, activities of acid phosphomonoesterase, alkaline phosphomonoesterase, and phosphodiesterase, and sequentially extractable $\mathrm{P}$ fractions. $\mathrm{P}$ additions as Minjingu PR yielded 299\% greater $\mathrm{P}_{\text {mic }}$ than TSP at $0-15-$ $\mathrm{cm}$ depth despite similar labile $\mathrm{P}$ concentrations in the two $\mathrm{P}$ fertilization treatments and stimulated activities of acid phosphomonoesterase (+39\%). When added in the soluble form of TSP, a greater percentage of total soil $\mathrm{P}$ was present in mineral-bound forms $(+33 \% \mathrm{Fe}$ - and $\mathrm{Al}$-associated $\mathrm{P})$. Higher soil $\mathrm{pH}$ under Minjingu PR ( $\mathrm{pH}$ 5.35) versus TSP $(\mathrm{pH} 5.02)$ and the P-unfertilized treatment $(\mathrm{pH} 4.69)$ at 0 15-cm depth reflected a liming effect of Minjingu PR. The
\end{abstract}

Electronic supplementary material The online version of this article (doi:10.1007/s00374-017-1226-9) contains supplementary material, which is available to authorized users.

Andrew J. Margenot

ajmargenot@gmail.com

1 Present address: Department of Crop Sciences, University of Illinois Urbana-Champaign, Urbana, Illinois 61801, USA

2 Department of Land, Air and Water Resources, University of California Davis, Davis, CA 95616, USA

3 Soils Program, International Center for Tropical Agriculture (CIAT), P.O. Box 823-00621, Nairobi, Kenya form of $\mathrm{P}$ fertilizer can influence biological $\mathrm{P}$ cycling in weathered soils, potentially improving $P$ availability under Minjingu PR relative to TSP via enhanced microbial biomass $P$ and enzymatic drivers of $P$ cycling.

Keywords Phosphorus $\cdot$ Phosphatase $\cdot$ Microbial biomass phosphorus · Oxisol $\cdot$ Phosphate rock $\cdot$ Kenya $\cdot$ Permanganate-oxidizable carbon

\section{Introduction}

Phosphorus (P) deficiency remains a key constraint to agricultural productivity in weathered soils of sub-Saharan Africa (Nziguheba et al. 2016). Ameliorating P deficiency can be accomplished by recapitalizing soils with $\mathrm{P}$ inputs (Buresh et al. 1996; Sanchez et al. 1997). Acidulated P fertilizers such as triple super phosphate (TSP) offer soluble and rapidly available P, but access and affordability limit their use by smallholder farmers (Jama and Kiwia 2009; Nziguheba et al. 2016). In many parts of sub-Saharan Africa, phosphate rock deposits are an economical alternative to TSP (Jama and Van Straaten 2006; Nandwa and Bekunda 1998). The largest high-quality deposit of PR $\left(10^{7} \mathrm{t}\right)$ in East Africa is Minjingu phosphate rock (PR) (Van Kauwenbergh 1991; van Straaten 2002). Though less soluble than TSP, Minjingu PR exhibits sufficient dissolution in acid, P-deficient soils to secure comparable or greater improvement of yields in the medium-term ( $>3$ years) (Szilas et al. 2007b). However, it is not known how P fertilization in the form of Minjingu PR versus TSP may affect biological cycling of soil $\mathrm{P}$, which in weathered soils is considered key to plant availability and could therefore modulate long-term response to $\mathrm{P}$ recapitalization strategies.

Soil microbial biomass and phosphatases are known to influence soil $\mathrm{P}$ availability in acid, weathered soils (Ayaga 
et al. 2006; Cui et al. 2015; Marschner 2008). Microbial biomass can serve as a reservoir of available $\mathrm{P}$ because microbial immobilization of soil solution $P$ avoids its geochemical capture (Oehl et al. 2001), and subsequent turnover of microbial biomass enables scavenged $\mathrm{P}$ to become transiently available to plants (Achat et al. 2010; Oberson and Joner 2005). Soil phosphatases are a class of enzymes that catalyze the mineralization of organic $\mathrm{P}\left(\mathrm{P}_{\mathrm{o}}\right)$ into plant-available inorganic $\mathrm{P}\left(\mathrm{P}_{\mathrm{i}}\right)$, and their activity is generally stimulated under conditions of $\mathrm{P}$ limitation (Nannipieri et al. 2011). Soil $P_{o}$ diester forms are first hydrolyzed by phosphodiesterases, with subsequent hydrolysis of resulting monoester $\mathrm{P}_{\mathrm{o}}$ forms to $\mathrm{P}_{\mathrm{i}}$ by acid and alkaline phosphomonoesterases (Tabatabai 1994; Turner and Haygarth 2005).

$\mathrm{P}$ inputs to agroecosystems are known to impact soil microbial biomass $\mathrm{P}\left(\mathrm{P}_{\mathrm{mic}}\right)$ and phosphatase activities, but the potential response of these biological drivers of $\mathrm{P}$ cycling to the form of P fertilizer type (e.g., phosphate rock versus TSP) remains unknown. Since microbial biomass can rapidly incorporate labile $\mathrm{P}$ (Bünemann et al. 2004c), additions of soluble $\mathrm{P}$ fertilizers such as TSP can increase $P_{\text {mic }}$ in weathered soils (Gichangi et al. 2010; Malik et al. 2012). On the other hand, a 5-year field experiment in western Kenya found that $\mathrm{P}_{\text {mic }}$ was not influenced by fertilization with TSP $(50 \mathrm{~kg}$ P $\mathrm{ha}^{-1}$ year $^{-1}$ ) (Bünemann et al. 2004a). Characterization of phosphatase activities in weathered soils under cultivation in East Africa is limited to a few studies and mostly acid phosphomonoesterase activity (Bossio et al. 2005; Mukuralinda et al. 2011; Radersma and Grierson 2004; Verchot and Borelli 2005). Despite the suppression of expression of phosphatases by $P_{i}$ (Nannipieri et al. 2011), TSP fertilization in weathered soils in this region at low $\left(25 \mathrm{~kg} \mathrm{P} \mathrm{ha}^{-1}\right)$ and high $\left(250 \mathrm{~kg} \mathrm{P} \mathrm{ha}^{-1}\right)$ rates did not decrease acid phosphomonoesterase activity (Mukuralinda et al. 2011; Radersma and Grierson 2004). However, it is not known how activities of acid phosphomonoesterase and additional phosphatases that modulate $\mathrm{P}$ cycling may be influenced by the form of $\mathrm{P}$ fertilizer in these agroecosystems.

Limited evidence suggests that the form of $\mathrm{P}$ fertilizer as Minjingu PR or TSP could influence biological P cycling in weathered soils in the short term. For example, within three cropping seasons, application of Minjingu PR to a weathered soil in western Kenya increased the population of $\mathrm{P}$ solubilizing bacteria (PSB) by up to $90 \%$, whereas TSP reduced the Psolubilizing bacteria population by 46-69\% (Ndungu-Magiroi et al. 2015). Since secretion of extracellular phosphatases is one of the $\mathrm{P}$ acquisition strategies employed by $\mathrm{P}$-solubilizing bacteria (Jones and Oburger 2011), Minjingu PR fertilization may have also engendered changes in soil phosphatase activities. However, the response of $\mathrm{P}_{\text {mic }}$ and phosphatase activities to management strategies was not characterized. Given the short-term instability of soil $\mathrm{P}$ dynamics in response to $\mathrm{P}$ fertilization in weathered soils (Beck and Sanchez 1994) and lag effects of lowly soluble Minjingu PR on soil P (Szilas et al. 2007b), long-term studies are necessary to address how $P$ fertilization in the form of Minjingu PR versus TSP may through microbial and enzymatic activities differentially impact soil $\mathrm{P}$ cycling.

We investigated the effect of $\mathrm{P}$ fertilizer on indicators of biological P cycling after 13 cropping seasons in an on-farm trial situated on a weathered soil in western Kenya. We evaluated the impact of $\mathrm{P}$ fertilization as Minjingu PR on soil $\mathrm{P}_{\text {mic }}$ and phosphatase activities relative to TSP, contextualized by soil $\mathrm{P}$ fractions. We hypothesized that at the same recommended $\mathrm{P}$ fertilization rate, Minjingu PR would increase $\mathrm{P}_{\text {mic }}$ and phosphatase activities relative to TSP.

\section{Methods}

\section{Site description and sampling}

The on-farm trial was established in 2007 in Sidada, in Siaya County in western Kenya $\left(34^{\circ} 24^{\prime} \mathrm{E}, 00^{\circ} 08^{\prime} \mathrm{N}\right)$ by the African Network for Soil Biology and Fertility program (AfNet) and was co-managed by the International Center for Tropical Agriculture (CIAT). The trial is designed to evaluate Minjingu PR and TSP added to maize (Zea mays)-based cropping systems. The region experiences a mean annual temperature of $23^{\circ} \mathrm{C}$ and mean annual precipitation of $1800 \mathrm{~mm}$ distributed over two rain seasons composed of a short rain period (September-November) and a period of long rain (March-June). The trial is situated on a Rhodic Kandiudox (USDA taxonomy) or Rhodic Acric Ferralsol (WRB taxonomy), with clay texture $\left(578 \mathrm{~g}\right.$ clay $\mathrm{kg}^{-1}, 207 \mathrm{~g}$ silt $\mathrm{kg}^{-1}$, $215 \mathrm{~g}$ sand $\mathrm{kg}^{-1}$ ) and $\mathrm{pH} 5.4$ at $0-30 \mathrm{~cm}$ depth in an adjacent uncultivated soil profile (Jelinski, unpublished). Further details are provided by Savini et al. (2016).

Two $P$ fertilization treatments were selected to represent Minjingu PR and TSP at $50 \mathrm{~kg} \mathrm{P} \mathrm{ha}^{-1}$ season $^{-1}$, a rate recommended for western Kenya (KARI 1994; Kihara and Njoroge 2013). Minjingu PR contained $12.8 \%$ total P, $23 \%$ of which is considered soluble as per neutral ammonium citrate extraction (Savini et al. 2016). TSP contained $45 \%$ P, $90 \%$ of which is soluble (Havlin et al. 2013). A P-unfertilized $\left(0 \mathrm{~kg} \mathrm{P} \mathrm{ha}^{-1}\right)$ treatment was also sampled as a control. Treatment plots $(6 \mathrm{~m} \times 6 \mathrm{~m})$ were cropped to maize in the long rains and common bean (Phaseolus vulgaris) in the short rains, with tillage and weeding performed by the farmer using a hand hoe. To highlight effects of $\mathrm{P}$ fertilization, all plots received background fertilization of $60 \mathrm{~kg}$ potassium $(\mathrm{K}) \mathrm{ha}^{-1}$ as muriate of potash and $60 \mathrm{~kg}$ nitrogen $(\mathrm{N}) \mathrm{ha}^{-1}$ as urea per season. All fertilizers, including P, were added by hand broadcasting as per local practices. After the 13th cropping season and prior to soil preparation for maize planting (e.g., tillage and fertilization), soils for individual treatment plots $(n=3$ per 
treatment) were sampled by auger as a plot composite $(n=3)$ at $0-15$ and $15-30 \mathrm{~cm}$ depths.

\section{General soil properties}

Soil $\mathrm{pH}$ was measured in deionized water (1:5) after $30 \mathrm{~min}$ of equilibration. Soil organic carbon (SOC) was determined with an ECS 4010 CHN Analyzer (Valencia, CA). Permanganateoxidizable $\mathrm{C}$ was determined using the method of Weil et al. (2003) as modified by Culman et al. (2012). Briefly, $2.50 \mathrm{~g}$ soil was oxidized with $0.02 \mathrm{M} \mathrm{KMnO}_{4}$ by 2 min shaking followed by 10 -min incubation. Non-reduced permanganate was quantified by colorimetry $(550 \mathrm{~nm})$.

\section{Soil $\mathbf{P}$ fractions}

Soil P distribution was assessed by sequential extraction. Triplicate soil samples ( $2 \mathrm{~g}$ ) were sequentially extracted (Hedley et al. 1982; Tiessen and Moir 1993). A negative control (no soil) and soil standard were also included. Anion-exchange membranes (AEM; $1 \times 4 \mathrm{~cm}$, VWR International, West Chester, PA) were loaded with carbonate as the counterion. Soils were extracted with AEM in deionized water by shaking for $18 \mathrm{~h}$. Inorganic $\mathrm{P}\left(\mathrm{P}_{\mathrm{i}}\right)$ was desorbed from the membranes by shaking for $3 \mathrm{~h}$ in $0.25 \mathrm{M}$ $\mathrm{H}_{2} \mathrm{SO}_{4}$. All other extracts were centrifuged $(8000 \times \mathrm{g}, 5 \mathrm{~min})$ and an aliquot decanted for analysis. For $\mathrm{NaOH}$ aliquots, organic matter was precipitated with $1.2 \mathrm{M} \mathrm{H}_{2} \mathrm{SO}_{4}$ and the precipitate was separated by centrifugation $(8000 \times \mathrm{g}$, $15 \mathrm{~min})$. Aliquots were neutralized and analyzed for $\mathrm{P}_{\mathrm{i}}$ and total $\mathrm{P}\left(\mathrm{P}_{\mathrm{t}}\right)$. Inorganic $\mathrm{P}$ was estimated by molybdate colorimetry at $880 \mathrm{~nm}$ (Murphy and Riley 1962). Total $P$ in aliquots was determined by the same procedure following acid-persulfate digestion $\left(80{ }^{\circ} \mathrm{C}, 16 \mathrm{~h}\right.$ ) (Rowland and Haygarth 1997). Organic $\mathrm{P}\left(\mathrm{P}_{\mathrm{o}}\right)$ was estimated as the difference between total and inorganic $\mathrm{P}$ (i.e., $\mathrm{P}_{\mathrm{o}}=\mathrm{P}_{\mathrm{t}}-\mathrm{P}_{\mathrm{i}}$ ). To simplify interpretation, Hedley fractions were considered to represent labile $\mathrm{P}\left(\mathrm{AEM}-\mathrm{P}_{\mathrm{i}}+\mathrm{NaHCO}_{3}-\mathrm{P}_{\mathrm{i}}\right), \mathrm{Fe}-$ and $\mathrm{Al}-$ associated $\mathrm{P}\left(\mathrm{NaOH}-\mathrm{P}_{\mathrm{i}}\right)$, Ca-associated $\mathrm{P}\left(\mathrm{HCl}-\mathrm{P}_{\mathrm{i}}\right)$, and organic $\mathrm{P}\left(\mathrm{NaHCO}_{3}-\mathrm{P}_{\mathrm{o}}+\mathrm{NaOH}-\mathrm{P}_{\mathrm{o}}\right)$ (Tiessen et al. 1983; Turrión et al. 2007). Total soil $\mathrm{P}$ was estimated independently by ashing $\left(550{ }^{\circ} \mathrm{C}, 1 \mathrm{~h}\right)$ followed by acid extraction (1 $\mathrm{M} \mathrm{H}_{2} \mathrm{SO}_{4}, 1: 50$ soil/extractant, $16 \mathrm{~h}$ ) and molybdate colorimetry (Dieter et al. 2010).

\section{Microbial biomass $\mathbf{P}\left(\mathbf{P}_{\text {mic }}\right)$}

$\mathrm{P}_{\text {mic }}$ was measured using sequential fumigation-extraction according to Brookes et al. (1982). Briefly, soils were preincubated for 2 weeks at $65 \%$ of water-filled pore space (WFPS). For each soil sample (i.e., treatment plot), three types of subsamples were processed: fumigated, non-fumigated, and spiked with $\mathrm{P}_{\mathrm{i}}$. Duplicate soil samples (2 g) were treated with chloroform gas for $18 \mathrm{~h}$ followed by extraction with 40-mL 0.5 $\mathrm{M} \mathrm{NaHCO}_{3}$ (pH 8.5, 1 h). Centrifugation was used to obtain a clear supernatant $(8000 \times \mathrm{g}, 15 \mathrm{~min})$, an aliquot of which was used to determine $\mathrm{P}_{\mathrm{i}}$ by molybdate colorimetry (Brookes et al. 1982; Murphy and Riley 1962). Nonfumigated and P-spiked subsamples were processed in the same way as fumigated subsamples, but without chloroform fumigation. A P spike (50 $\mathrm{g} \mathrm{P} \mathrm{g}^{-1}$ soil) was used to estimate $P$ recovery in fumigated samples. $P_{\text {mic }}$ was calculated as the difference between fumigated and non-fumigated extractable $\mathrm{P}$ and corrected for $\mathrm{P}$ spike recovery.

In order to evaluate the relative magnitude of soil $\mathrm{P}$ stored in microbial biomass, $\mathrm{P}_{\text {mic }}$ was expressed as a percent of total soil $\mathrm{P}$. As $\mathrm{P}_{\text {mic }}$ is considered a potentially plant-available $\mathrm{P}$ pool in weathered soils (Ayaga et al. 2006), the ratio of $\mathrm{P}_{\text {mic }}$ to labile $\mathrm{P}$ was calculated to evaluate the relative proportions of these two measures of potentially available P.

\section{Soil phosphatase activities}

Acid phosphomonoesterase (Enzyme Commission 3.1.3.2), alkaline phosphomonoesterase (EC 3.1.3.1), and phosphodiesterase (EC 3.1.4.1) activities were assayed as described by Tabatabai (1994), using $1 \mathrm{~g}$ of air-dried soil incubated for $1 \mathrm{~h}$ at $37^{\circ} \mathrm{C}$ in $4-\mathrm{mL}$ modified universal buffer (MUB) at $\mathrm{pH} 6.5$ for acid phosphomonoesterase and at $\mathrm{pH} 11.0$ for alkaline phosphomonoesterase, or in 4-mL 0.05 M Tris (2-amino2-(hydroxymethyl)-1,3-propanediol) buffer at $\mathrm{pH} 8.0$ for phosphodiesterase. Assays employed a final substrate concentration of $0.01 \mathrm{M}$ para-nitrophenyl phosphate (acid phosphomonoesterase and alkaline phosphomonoesterase) or bispara-nitrophenyl phosphate (phosphodiesterase). A negative control (no soil) and a positive control (lab soil standard) were also included. Reactions were halted by the addition of 4-mL $0.5 \mathrm{M} \mathrm{NaOH}$ to acid phosphomonoesterase and alkaline phosphomonoesterase assays or 4-mL $0.1 \mathrm{M}$ Tris $(\mathrm{pH} 12.0)$ to phosphodiesterase assays, and $1-\mathrm{mL} 0.5 \mathrm{M} \mathrm{CaCl}_{2}$. Assays were centrifuged $(8000 \times g, 4 \mathrm{~min})$ to remove sediment, and para-nitrophenol ( $p \mathrm{NP})$ in the clear supernatant was quantified colorimetrically at $410 \mathrm{~nm}$. Absorbance from the negative controls was subtracted from absorbance of soil assays.

\section{Statistical analyses}

The effect of $\mathrm{P}$ fertilizer form (Minjingu PR vs TSP) on soil properties was evaluated with pairwise $t$ tests using Proc TTEST in SAS v.9.4 (Cary Institute, NC). To evaluate the effect of P-fertilization, Dunnett's test was used to compare response of Minjingu PR and TSP relative to the $\mathrm{P}$ unfertilized control using Proc GLM. Comparison of Minjingu PR and TSP ( $t$ test) is reported in tables, whereas comparisons between Minjingu PR, TSP, and P-unfertilized treatments are reported in the text and/or in a Supplementary 
Table. Relationships among soil properties across treatments and depths were evaluated by Pearson correlation analysis using Proc CORR with the correlation coefficient $(R)$ and significance ( $p$ value).

\section{Results}

\section{Soil properties}

Soil properties showed weak differences between Minjingu PR and TSP after 13 cropping seasons, though $\mathrm{P}$ inputs increased soil $\mathrm{pH}$ and permanganate-oxidizable $\mathrm{C}$ compared to no $\mathrm{P}$ fertilization (Table 1, Supplementary Table 1). Soil pH was elevated under Minjingu PR relative to TSP at $0-15 \mathrm{~cm}$ depth $(p=0.097)$. Though permanganate-oxidizable $\mathrm{C}$ did not differ by P fertilizer form, Minjingu PR increased SOC (+10\%) at 15$30 \mathrm{~cm}$ depth $(p=0.069)$ compared to TSP, a trend that was weaker at $0-15 \mathrm{~cm}$ depth $(p=0.132)$. Concurrent with elevated $\mathrm{SOC}$, soil $\mathrm{C} / \mathrm{P}_{\mathrm{o}}$ was greater at $15-30 \mathrm{~cm}$ depth under Minjingu $\mathrm{PR}\left(\mathrm{C} / \mathrm{P}_{\mathrm{o}} 226\right)$ compared to $\mathrm{TSP}\left(\mathrm{C} / \mathrm{P}_{\mathrm{o}} 209\right)(p=0.093)$, and only under Minjingu PR was significantly elevated relative to the P-unfertilized control (Supplementary Table 1). P fertilization using Minjingu PR but not TSP significantly increased soil $\mathrm{pH}$ relative to no $\mathrm{P}$ fertilization at both depths (e.g., $\mathrm{pH} 4.69$ vs 5.35 at $0-15 \mathrm{~cm}, p=0.025)$, and $\mathrm{P}$ fertilization increased permanganate-oxidizable $\mathrm{C}$ by a mean of $35 \%$ at $0-15 \mathrm{~cm}$ depth $(p=0.0003)$ (Supplementary Table 1).

\section{Soil $P$ pools}

Soil $\mathrm{P}$ fractions indicated greater $\mathrm{P}$ availability of $\mathrm{P}$ added as Minjingu PR than as TSP (Table 2). Minjingu PR yielded $89 \%$ greater labile $\mathrm{P}$ at $15-30 \mathrm{~cm}$ depth compared to TSP
( $p=0.040)$. Concurrent with lower labile $\mathrm{P}$, TSP additions resulted in $33 \%$ greater $\mathrm{Fe}$ - and $\mathrm{Al}$-associated $\mathrm{P}$ at $0-15 \mathrm{~cm}$ depth. Organic $\mathrm{P}$ and $\mathrm{Ca}$-associated $\mathrm{P}$ did not differ between $\mathrm{P}$ fertilizers. Though total $P$ was higher under TSP at $0-15 \mathrm{~cm}$ depth $(p=0.045)$, there was no difference in total $\mathrm{P}$ at $0-30 \mathrm{~cm}$ depth by the form of $\mathrm{P}$ fertilizer $(p=0.25)$. $\mathrm{P}$ fertilization for 13 cropping seasons produced significant increases in $\mathrm{P}$ pools at both depths relative to no $\mathrm{P}$ fertilization except organic $\mathrm{P}$, which decreased at $0-15 \mathrm{~cm}$ depth with $\mathrm{P}$ fertilization.

\section{Microbial biomass $\mathbf{P}\left(\mathbf{P}_{\text {mic }}\right)$}

The form of $\mathrm{P}$ fertilizer had a significant effect on $\mathrm{P}_{\text {mic }}$ at 0 $15 \mathrm{~cm}$ depth (Fig. 1). Mean $\mathrm{P}_{\text {mic }}$ was $299 \%$ greater under Minjingu PR (23.1 $\left.\mathrm{Mg} \mathrm{g}^{-1}\right)$ than TSP $\left(5.3 \mu \mathrm{g} \mathrm{g}^{-1}\right)$. $\mathrm{P}_{\text {mic }}$ was significantly elevated under Minjingu PR but not TSP relative to the P-unfertilized control $\left(2.8 \mu \mathrm{g} \mathrm{g}^{-1}\right)$. Additionally, $\mathrm{P}_{\text {mic }}$ represented a greater percentage of total soil $\mathrm{P}$ under Minjingu PR $(3.5 \%)$ than under TSP $(0.8 \%)$ at $0-15 \mathrm{~cm}$ depth, which was similar to no $\mathrm{P}$ fertilization $(0.6 \%)$ (Fig. 2). The percentage of $\mathrm{P}_{\text {mic }}$ relative to labile $\mathrm{P}$ at $0-15 \mathrm{~cm}$ depth was greater under Minjingu PR $\left(\mathrm{P}_{\text {mic }} / \mathrm{P}_{\text {labile }}=0.59\right)$ relative to TSP $\left(\mathrm{P}_{\text {mic }} /\right.$ $\mathrm{P}_{\text {labile }}=0.13$ ) (Fig. 3).

At $15-30 \mathrm{~cm}$ depth, $\mathrm{P}_{\text {mic }}$ was similar between Minjingu PR $\left(9.4 \mu \mathrm{g} \mathrm{g}^{-1}\right)$ and TSP $\left(6.8 \mu \mathrm{g} \mathrm{g}^{-1}\right)$ (Fig. 1) and represented a similar percentage of total and labile $\mathrm{P}$ between $\mathrm{P}$ fertilizer forms (Fig. 2). At 15-30 cm depth, P fertilization increased $\mathrm{P}_{\text {mic }}$ by $343 \%$ from $1.8 \mu \mathrm{g} \mathrm{g}^{-1}$ (P-unfertilized) to $8.1 \mu \mathrm{g} \mathrm{g}^{-1}$ (Minjingu PR, TSP) (Fig. 3). $\mathrm{P}_{\text {mic }}$ was positively correlated with total and labile $\mathrm{P}$ across treatments and depths (e.g., $\mathrm{R}_{\text {labile } P}=0.61, p=0.0075$ ) (Supplementary Table 2). Excluding TSP treatment for $0-15 \mathrm{~cm}$ depth revealed a stronger correlation of $\mathrm{P}_{\text {mic }}$ and labile $\mathrm{P}(R=0.91, p<0.0001)$. $\mathrm{P}_{\text {mic }}$ was positively correlated with $\mathrm{pH}(R=0.46, p=0.053)$,
Table 1 Soil properties in a Rhodic Kandiudox in western Kenya following 13 cropping seasons of fertilization with Minjingu phosphate rock (PR) or triple super phosphate (TSP)

\begin{tabular}{|c|c|c|c|c|c|c|c|c|}
\hline & \multicolumn{2}{|l|}{$\mathrm{pH}$} & \multicolumn{2}{|c|}{$\operatorname{SOC}\left(\mathrm{mg} \mathrm{g}^{-1}\right)$} & \multicolumn{2}{|c|}{ POXC $\left(\mu g^{-1}\right)$} & \multicolumn{2}{|l|}{$\mathrm{C} / \mathrm{P}_{\mathrm{o}}$} \\
\hline & mean & se & Mean & se & mean & se & mean & se \\
\hline \multicolumn{9}{|l|}{$0-15 \mathrm{~cm}$} \\
\hline Minjingu PR & 5.35 & 0.08 & 19.7 & 0.6 & 362 & 15 & 222 & 21 \\
\hline TSP & 5.02 & 0.13 & 18.0 & 0.6 & 331 & 31 & 179 & 12 \\
\hline P-unfertilized & 4.69 & 0.08 & 18.0 & 0.5 & 256 & 16 & 154 & 6 \\
\hline$p$ & 0.097 & & 0.132 & & 0.388 & & 0.149 & \\
\hline \multicolumn{9}{|l|}{$15-30 \mathrm{~cm}$} \\
\hline Minjingu PR & 5.39 & 0.04 & 19.0 & 0.6 & 279 & 32 & 226 & 5 \\
\hline TSP & 5.35 & 0.13 & 17.3 & 0.6 & 263 & 12 & 209 & 4 \\
\hline P-unfertilized & 5.04 & 0.04 & 17.3 & 0.3 & 255 & 56 & 183 & 8 \\
\hline$p$ & 0.790 & & 0.069 & & 0.642 & & 0.093 & \\
\hline
\end{tabular}

Significance ( $p$ value) between Minjingu PR and TSP treatments was determined by pairwise $t$ test. A Punfertilized treatment is included as a reference

se standard error, $C / P_{o}$ ratio of total $\mathrm{C}$ to organic $\mathrm{P}, S O C$ soil organic $\mathrm{C}, P O X C$ permanganate-oxidizable $\mathrm{C}$ 
Table 2 Soil P fractions $\left(\mu \mathrm{g} \mathrm{g}^{-1}\right)$ in a Rhodic Kandiudox in western Kenya following fertilization with Minjingu phosphate rock (PR) or triple super phosphate (TSP) over 13 cropping seasons

\begin{tabular}{|c|c|c|c|c|c|c|c|c|c|c|}
\hline & \multicolumn{2}{|c|}{ Labile P } & \multicolumn{2}{|c|}{ Organic P } & \multicolumn{2}{|c|}{ Fe-, Al-P } & \multicolumn{2}{|l|}{ Ca-P } & \multicolumn{2}{|l|}{ Total P } \\
\hline & mean & $\mathrm{se}$ & mean & se & mean & se & mean & se & mean & se \\
\hline \multicolumn{11}{|l|}{$0-15 \mathrm{~cm}$} \\
\hline Minjingu PR & 38.3 & 3.2 & 89.7 & 6.7 & 143.9 & 8.4 & 3.2 & 0.3 & 663.7 & 9.3 \\
\hline TSP & 46.1 & 2.9 & 100.5 & 1.9 & 191.4 & 11.3 & 2.7 & 0.3 & 717.2 & 16.6 \\
\hline P-unfertilized & 2.5 & 0.2 & 117.3 & 2.6 & 63.3 & 2.9 & 1.0 & 0.1 & 454.6 & 6.0 \\
\hline$P$ & 0.092 & & 0.16 & & 0.004 & & 0.31 & & 0.045 & \\
\hline \multicolumn{11}{|l|}{$15-30 \mathrm{~cm}$} \\
\hline Minjingu PR & 15.9 & 3.0 & 94.9 & 11.8 & 71.1 & 10.0 & 1.3 & 0.1 & 534.2 & 30.7 \\
\hline TSP & 8.4 & 1.5 & 83.0 & 4.1 & 67.4 & 8.7 & 1.1 & 0.2 & 460.3 & 14.0 \\
\hline P-unfertilized & 0.9 & 0.0 & 94.9 & 2.7 & 26.8 & 0.8 & 1.1 & 0.1 & 390.1 & 3.1 \\
\hline$P$ & 0.040 & & 0.36 & & 0.79 & & 0.255 & & 0.10 & \\
\hline
\end{tabular}

Labile $\mathrm{P}$ is the sum of anion-exchange membrane extractable $\mathrm{P}_{\mathrm{i}}$ and sodium bicarbonate extractable $\mathrm{P}_{\mathrm{i}}$, organic $\mathrm{P}$ is the sum of sodium bicarbonate extractable $\mathrm{P}_{\mathrm{o}}$ and sodium hydroxide extractable $\mathrm{P}_{\mathrm{o}}, \mathrm{Fe}-$, and $\mathrm{Al}$-associated $\mathrm{P}$ is sodium hydroxide extractable $\mathrm{P}_{\mathrm{i}}$, and Ca-associated $\mathrm{P}$ is hydrochloric acid extractable $\mathrm{P}_{\mathrm{i}}$. Significance ( $p$ value) between Minjingu PR and TSP treatments was determined by pairwise $t$ test. A P-unfertilized treatment is included as a reference

se standard error, $P_{i}$ inorganic $\mathrm{P}, P_{o}$ organic $\mathrm{P}$ permanganate-oxidizable $\mathrm{C}(R=0.48, p=0.046)$ and $\mathrm{C} / \mathrm{P}_{\mathrm{o}}$ $(R=0.62, p=0.0062)$, but not organic $\mathrm{P}$.

\section{Phosphatase activities}

Activities of particular soil phosphatases were elevated under P fertilization with Minjingu PR than with TSP (Fig. 4). At 0-

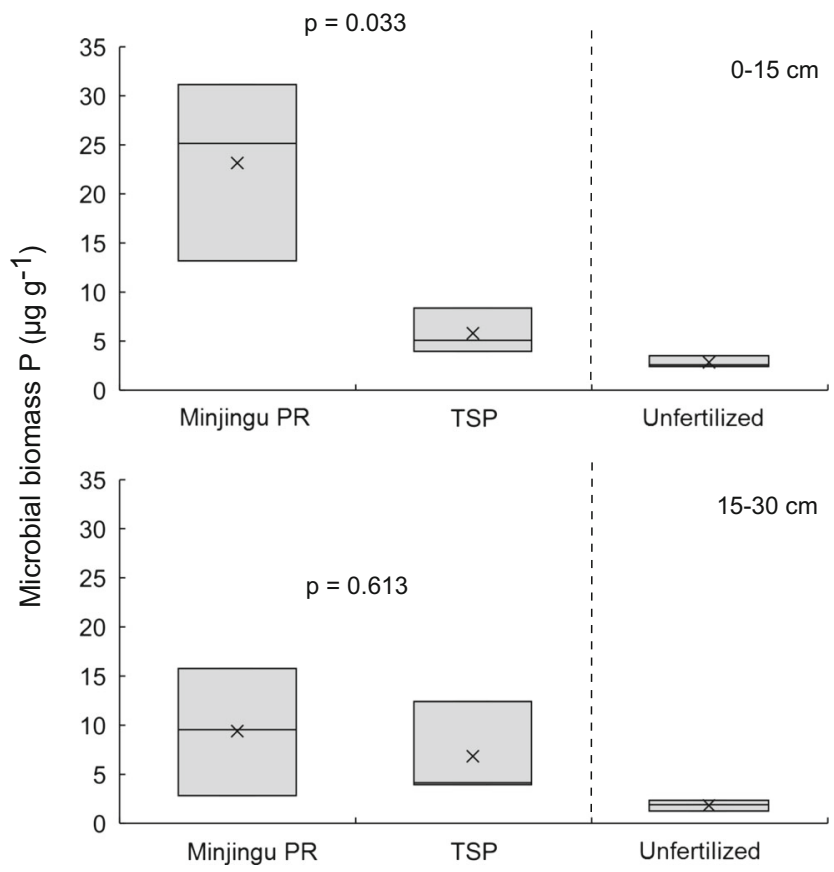

Fig. 1 Soil microbial biomass $\mathrm{P}\left(\mathrm{P}_{\text {mic }}\right)$ in a Rhodic Kandiudox in western Kenya following 13 cropping seasons of fertilization with Minjingu phosphate rock (PR) or triple super phosphate (TSP) at $50 \mathrm{~kg} \mathrm{P} \mathrm{ha}^{-1}$ season $^{-1}$, with a P-unfertilized control as a reference
$15 \mathrm{~cm}$ depth, acid phosphomonoesterase was $39 \%$ greater under Minjingu PR $\left(4.8 \mu \mathrm{mol} p \mathrm{NP} \mathrm{g}^{-1} \mathrm{~h}^{-1}\right)$ than under TSP (3.4 $\mu \mathrm{mol} p \mathrm{NP} \mathrm{g}^{-1} \mathrm{~h}^{-1}$ ). At $15-30 \mathrm{~cm}$ depth, phosphodiesterase was elevated under Minjingu PR $\left(1.8 \mu \mathrm{mol} p \mathrm{NP} \mathrm{g}^{-1} \mathrm{~h}^{-1}\right)$ compared to TSP $\left(1.4 \mu \mathrm{mol} p \mathrm{NP} \mathrm{g}^{-1} \mathrm{~h}^{-1}\right)(p=0.10)$. Across depths, activities of acid phosphomonoesterase and alkaline phosphomonoesterase were positively correlated $(R=0.80$, $p=0.0017)$, but only alkaline phosphomonoesterase activity

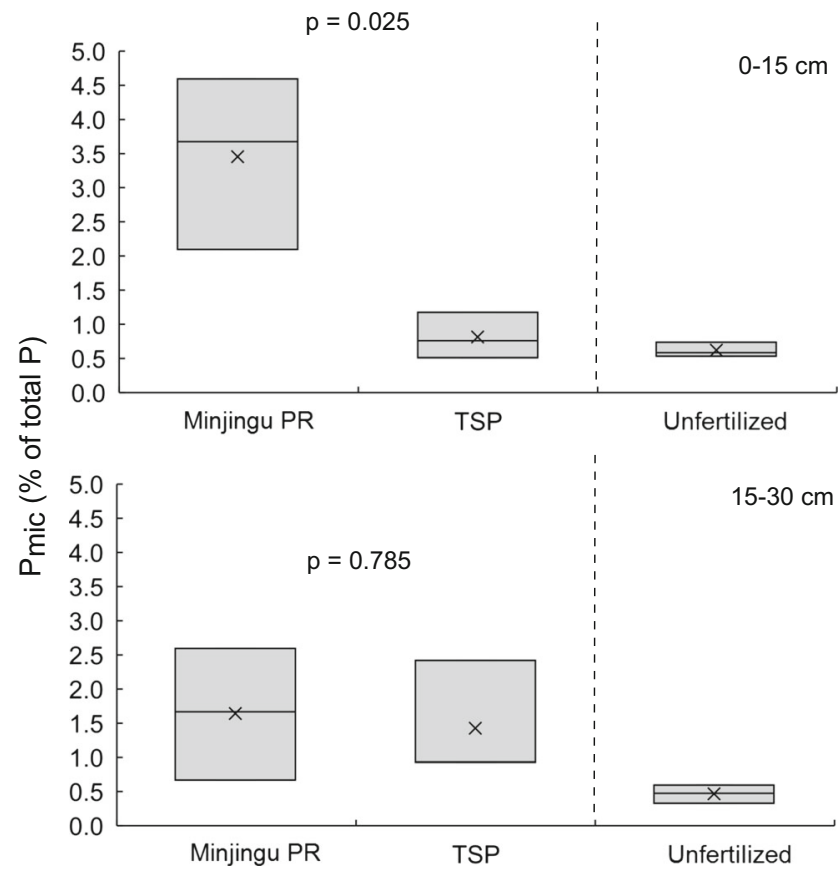

Fig. 2 Soil microbial biomass $\mathrm{P}\left(\mathrm{P}_{\mathrm{mic}}\right)$ as a percentage of total soil $\mathrm{P}$ following fertilization for 13 cropping seasons with Minjingu phosphate rock (PR) or triple super phosphate (TSP) at $50 \mathrm{~kg} \mathrm{P} \mathrm{ha}^{-1}$ season $^{-1}$, with a P-unfertilized control as a reference 


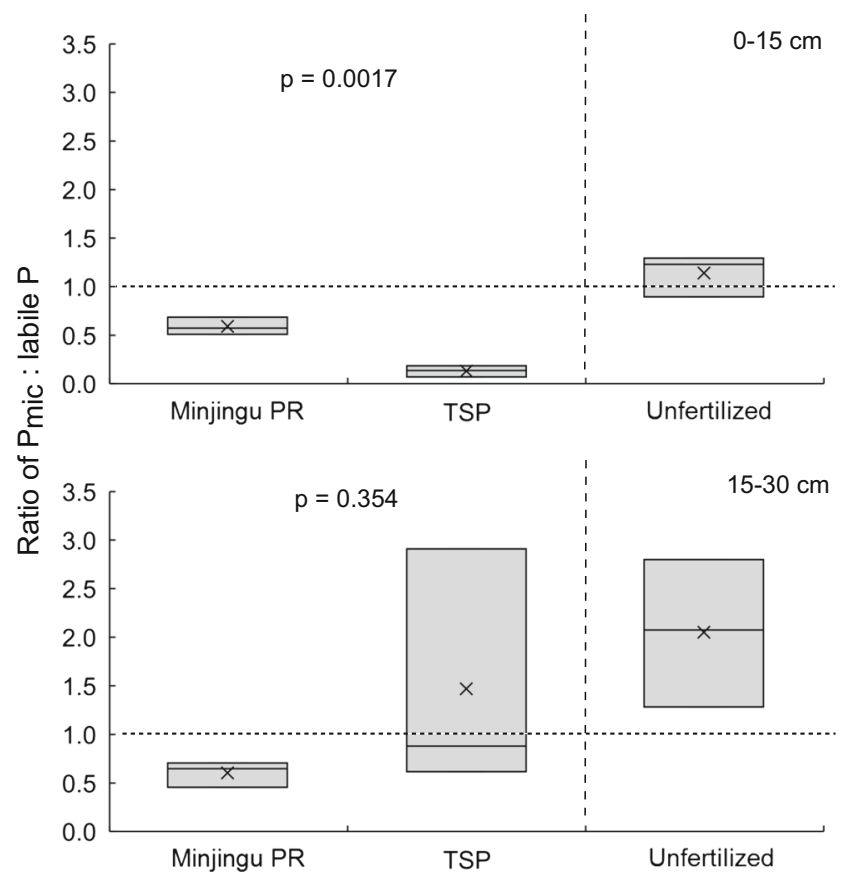

Fig. 3 Proportion of soil microbial biomass $\mathrm{P}\left(\mathrm{P}_{\mathrm{mic}}\right)$ relative to labile $\mathrm{P}$ $\left(\mathrm{P}_{\mathrm{mic}} /\right.$ labile $\left.\mathrm{P}\right)$, following fertilization for 13 cropping seasons with Minjingu phosphate rock (PR) or triple super phosphate (TSP) at $50 \mathrm{~kg}$ $\mathrm{P} \mathrm{ha}^{-1}$ season $^{-1}$, with a P-unfertilized control as a reference

was correlated with phosphodiesterase activity $(R=0.64$, $p=0.0046$ ) (Supplementary Table 2). Activity of acid

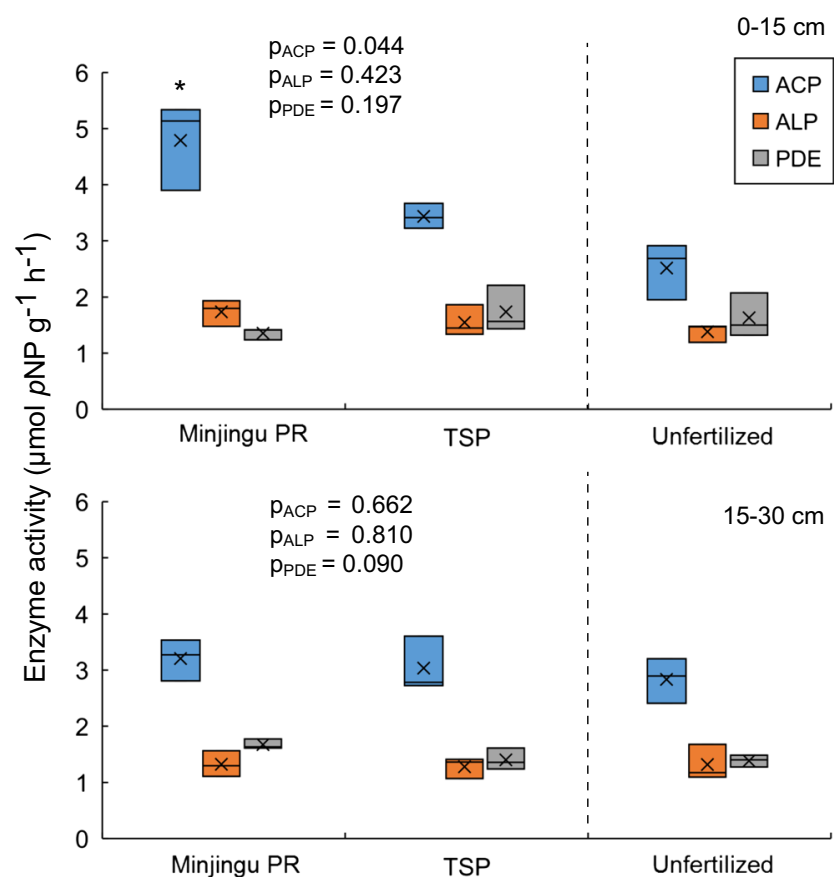

Fig. 4 Activities of acid phosphomonoesterase (ACP), alkaline phosphomonoesterase (ALP), and phosphodiesterase (PDE) determined by para-nitrophenol assay in a Rhodic Kandiudox in western Kenya following 13 cropping seasons of fertilization with Minjingu phosphate rock (PR) or triple super phosphate (TSP) at $50 \mathrm{~kg} \mathrm{P} \mathrm{ha}^{-1}$ season $^{-1}$, with a $\mathrm{P}$-unfertilized control as a reference phosphomonoesterase was higher under $\mathrm{P}$ fertilization (mean $+80 \%$ ) relative to no $\mathrm{P}$ fertilization at $0-15 \mathrm{~cm}$ depth. Phosphatase activities were positively correlated with SOC, labile $\mathrm{P}$, and total $\mathrm{P}$, but not organic $\mathrm{P} . \mathrm{P}_{\text {mic }}$ was correlated with acid phosphomonoesterase $(R=0.69, p=0.0015)$ and alkaline phosphomonoesterase $(p=0.039)$, but not phosphodiesterase $(p=0.29)$ (Supplementary Table 2). Across the $\mathrm{pH}$ range encompassed by treatments ( $\mathrm{pH} 4.69-5.35$, Table 1 ), the activity of alkaline phosphomonoesterase and acid phosphomonoesterase but not phosphodiesterase increased with soil $\mathrm{pH}$ (e.g., for alkaline phosphomonoesterase $R=0.61$, $p=0.0072$ ), and a similar trend occurred for permanganateoxidizable C.

\section{Discussion}

\section{Increases in microbial biomass $\mathbf{P}$ with phosphate rock fertilization}

The hypothesized effect of $\mathrm{P}$ fertilizer type on microbial biomass $\mathrm{P}$ was supported by increases in $\mathrm{P}_{\text {mic }}$ under Minjingu PR. A greater percentage of total $P$ as $P_{\text {mic }}$ under Minjingu PR relative to TSP suggests greater availability of $\mathrm{P}$ added as $\mathrm{PR}$. This is consistent with higher Fe- and $\mathrm{Al}$-associated $\mathrm{P}\left(\mathrm{NaOH}-\mathrm{P}_{\mathrm{i}}\right)$ under TSP, which indicates greater geochemical capture and thus lower plant availability of $\mathrm{P}$ added in the soluble form of TSP compared to less soluble inputs such as PR (e.g., Loganathan et al. 1982; Nziguheba et al. 1998; Rivaie et al. 2008; Zoysa et al. 2001). Increases in $\mathrm{Fe}$ - and $\mathrm{Al}$-associated $\mathrm{P}$ under soluble additions of $\mathrm{P}$ such as TSP have been proposed to result from the lack of synchrony between its rapid solubilization following application and crop P uptake (Savini et al. 2006, 2016; Zoysa et al. 2001). In addition to greater extractable available $\mathrm{P}\left(\mathrm{AEM}-\mathrm{P}_{\mathrm{i}}+\mathrm{NaHCO}_{3}-\mathrm{P}_{\mathrm{i}}\right)$, the ratio of $\mathrm{P}_{\text {mic }}$ to labile $\mathrm{P}$ indicates that a greater percentage of $\mathrm{P}$ applied in the form of Minjingu PR is potentially plantavailable as $P_{\text {mic }}$ (Oberson et al. 2006, 2011). Effects of Minjingu PR on soil microbial biomass may reflect a combination of low solubility $\mathrm{P}$ additions and liming effects because previous studies indicate that increasing $\mathrm{pH}$ alone does not necessarily lead to greater $\mathrm{P}_{\text {mic }}$ unless combined with low solubility P such as PR (He et al. 1997).

\section{Stimulation of phosphatase activity under $P$ fertilization}

This study demonstrates that P fertilization with PR can stimulate phosphatase activity relative to more soluble fertilizer forms such as TSP. Greater acid phosphomonoesterase activity under Minjingu PR relative to TSP could be explained by elevated P-solubilizing bacteria populations observed after only 3 cropping systems at our site (Ndungu-Magiroi et al. 
2015) because P-solubilizing bacteria secrete phosphatases as part of their P acquisition portfolio (Jones and Oburger 2011). On the other hand, alkaline phosphomonoesterase activity did not respond to $\mathrm{P}$ fertilizer form, though it is considered to be solely of microbial origin (Nannipieri et al. 2011; Spohn and Kuzyakov 2013a) and in weathered soils can be more sensitive than acid phosphomonoesterase to management (Cui et al. 2015). Greater activity of acid phosphomonoesterase, but not alkaline phosphomonoesterase and phosphodiesterase, under Minjingu PR relative to TSP, and under $\mathrm{P}$ fertilization relative to no P-fertilization, may be mediated by changes in $\mathrm{pH}$. Fertilization with Minjingu PR shifted soil $\mathrm{pH}$ toward the optimum for acid phosphomonoesterase activity ( $\mathrm{pH} 5.2$; Hui et al. 2013), but still considerably below the $\mathrm{pH}$ considered optimal for alkaline phosphomonoesterase ( $\mathrm{pH} 11)$ or phosphodiesterase ( $\mathrm{pH} \mathrm{8)}$ (Tabatabai 2003). In order to improve understanding of $\mathrm{P}$ fertilizer impacts on soil phosphatase activities, future work should consider the relationship between soil phosphatase activities and genes encoding phosphatases because this approach can identify phosphatase origins (e.g., microbial vs fungal) (Acuña et al. 2016; Lagos et al. 2016; Ragot et al. 2017) and how microbial community response to management may translate to changes in phosphatase activity (Cui et al. 2015).

\section{Benefits of $P$ fertilization for microbial and enzymatic $P$ cycling}

This study identifies positive impacts of $\mathrm{P}$ fertilization on the microbial and enzyme activity components of soil P cycling in a weathered soil. Increased $\mathrm{P}_{\text {mic }}$ following 13 cropping seasons of $\mathrm{P}$ inputs relative to a $\mathrm{P}$-unfertilized control supports previous findings of $\mathrm{P}_{\text {mic }}$ increases following $\mathrm{P}$ addition to weathered soils with low available P (e.g., Gichangi et al. 2010; Mukuralinda et al. 2011). In the P-unfertilized control, the high ratio of $\mathrm{P}_{\text {mic }}$ to labile $\mathrm{P}$ demonstrates the greater relative magnitude of $\mathrm{P}_{\text {mic }}$ as a plant-available $\mathrm{P}$ pool in $\mathrm{P}$ deficient soils (Oberson et al. 2006, 2011). However, a greater percentage of total $\mathrm{P}$ as $\mathrm{P}_{\text {mic }}$ under Minjingu $\mathrm{PR}$ relative to TSP and P-unfertilized treatments suggests greater accessibility of $\mathrm{P}$ from Minjingu PR to soil microbes. This may reflect the potential of poorly soluble inputs such as Minjingu PR to stimulate P-efficient microbial communities (see "Stimulation of phosphatase activity under P fertilization") and greater fixation of $\mathrm{P}$ added as TSP (i.e., Fe- and Al-associated P).

Our study additionally demonstrates that $\mathrm{P}$ fertilization does not necessarily suppress phosphatase activities in weathered soils. Activity of acid phosphomonoesterase is generally thought to increase in response to $\mathrm{P}$ deficiency (Nannipieri et al. 2011; Vance 2008; Vance et al. 2003), but acid phosphomonoesterase and phosphodiesterase activities in P-fertilized soils were higher than in the P-unfertilized (and P-deficient) soils at our site, and higher than in P-deficient weathered soils in a separate study also in western Kenya (Verchot and Borelli 2005). P fertilization is considered to decrease phosphatase activity because $P_{i}$ can inhibit microbial expression of these enzymes (Nannipieri et al. 2011). For example, inverse associations between phosphatase activity and soil $\mathrm{P}_{\mathrm{i}}$ have been observed in weathered soils in tropical forests (Olander and Vitousek 2000). In contrast, at our site, $\mathrm{P}_{\mathrm{i}}$ fractions were not negatively correlated with phosphatase activities, consistent with a lack of acid phosphomonoesterase suppression in Oxisols following high $\mathrm{P}$ additions $\left(250 \mathrm{~kg} \mathrm{P} \mathrm{ha}^{-1}\right)$ in this region (Radersma and Grierson 2004). Similarly, acid phosphomonoesterase suppression did not occur in Oxisols in Brazil following 6 years of cumulative $\mathrm{P}$ application of up to $549 \mathrm{~kg} \mathrm{P} \mathrm{ha}{ }^{-1}$ (Conte et al. 2002) and $797 \mathrm{~kg} \mathrm{P} \mathrm{ha}^{-1}$ (Costa et al. 2013). In some cases, $P$ fertilization at rates comparable or greater than in this study elevated acid phosphomonoesterase activities, which was attributed to increased SOC (Alvear et al. 2005), organic P (Redel et al. 2007), and microbial biomass (Costa et al. 2013).

Stimulation of phosphatase activities in weathered soils by $\mathrm{P}$ fertilization could reflect indirect effects of lifting $\mathrm{P}$ constraints to crop productivity. Relieving nutrient limitation favors increased crop biomass production and as a result greater residue additions to soil (Geisseler and Scow 2014; Körschens et al. 2013; Ladha et al. 2011). This is consistent with greater labile and total soil $\mathrm{C}$, and acid phosphomonoesterase activity under $\mathrm{P}$ fertilization relative to no P-fertilization at our site. Soil $\mathrm{C}$ increases from increased biomass production may stimulate phosphatase activities because mineralization of $\mathrm{P}_{\mathrm{o}}$ can be driven by microbial demand for C (Heuck et al. 2015; Spohn and Kuzyakov 2013b), and C has been found to be more limiting than $\mathrm{P}$ in P-fertilized weathered soils in western Kenya (Bünemann et al. 2004a, b). P fertilization may have also increased acid phosphomonoesterase activity via enhanced root biomass, because plant roots can be a major source of this phosphatase (Nannipieri et al. 2011; Renella et al. 2006). For example, increases in acid phosphomonoesterase in grassland soils receiving $\mathrm{N}$ and $\mathrm{P}(10 \mathrm{~g} \mathrm{~N}, \mathrm{P}$ $\mathrm{m}^{-2}$ year ${ }^{-1}$ ) compared to unfertilized grassland soils were partly attributed to the nearly doubling of root biomass as a result of fertilization (Tian et al. 2016).

Greater permanganate-oxidizable $\mathrm{C}$ and a trend toward greater SOC indicate under $\mathrm{P}$ fertilization demonstrates that alleviating $\mathrm{P}$ deficiency can positively impact SOM cycling. This is in agreement with evidence that SOM accrual in weathered soils is strongly limited by nutrient scarcity (Kirkby et al. 2013). Increases in permanganateoxidizable $\mathrm{C}$ and a trend toward greater SOC with $\mathrm{P}$ fertilization are consistent with evidence that permanganateoxidizable $\mathrm{C}$ can be an early indicator of SOM accrual (Lucas and Weil 2012; Weil et al. 2003) and is associated with management practices that promote SOM stabilization (Hurisso et al. 2016). 


\section{Liming effects of $P$ fertilizers}

Phosphate rock additions can have a moderate liming effect $\left(\mathrm{CaCO}_{3}\right.$ equivalency $>50 \%$ ) (Sikora 2002) due to proton consumption by PR dissolution, base cation addition $\left(\mathrm{Ca}^{2+}\right.$, $\mathrm{Mg}^{2+}$ ), and $\mathrm{CO}_{3}{ }^{-}$addition in sedimentary PRs such as Minjingu PR (Chien 1977). At $68 \% \mathrm{CaCO}_{3}$ equivalency, Minjingu PR can be considered a low-grade liming agent (Nekesa et al. 2005), which explains observed pH increases under Minjingu PR additions in this and other studies across East Africa (Szilas et al. 2007b). Assuming a CCE of 68\% and given the $12.8 \% \mathrm{P}$ content of Minjingu PR applied at $50 \mathrm{~kg} \mathrm{P}$ $\mathrm{ha}^{-1}$ season $^{-1}$, an equivalent of $3.5 \mathrm{tlime} \mathrm{ha}{ }^{-1}$ had been applied at the time of sampling. Such repeated low-dose liming $\left(0.27 \mathrm{t} \mathrm{ha}^{-1}\right.$ season $\left.^{-1}\right)$ via Minjingu PR explains its elevation of soil $\mathrm{pH}(\mathrm{pH} 5.35)$ relative to no $\mathrm{P}$ fertilization $(\mathrm{pH} 4.69)$ and TSP ( $\mathrm{pH}$ 5.02). Lesser increases in $\mathrm{pH}$ under TSP are attributable to its negligible $\mathrm{CaCO}_{3}$ equivalency and lower $\mathrm{Ca}$ content (12-14\%) compared to Minjingu PR (27\%) (Havlin et al. 2013; Savini et al. 2016; Szilas et al. 2007b). Liming of weathered soils in western Kenya can improve the availability of native and added $\mathrm{P}$ by reducing exchangeable $\mathrm{Al}^{3+}$ and elevating soil pH (Kisinyo et al. 2014, 2015). Thus, Minjingu PR offers benefits beyond recapitalization of soil $\mathrm{P}$ for weathered soils in western Kenya.

In addition to indirect effects on soil P cycling by liming, additions of $\mathrm{P}$ in the form of Minjingu PR likely contributed greater amounts of nutrients than TSP. The addition of these nutrients, including $\mathrm{Ca}, \mathrm{Mg}, \mathrm{K}, \mathrm{Cu}$, and $\mathrm{Zn}$ (Szilas et al. 2007a; Van Kauwenbergh 1991), may explain greater $P_{\text {mic }}$ under Minjingu PR relative to TSP. Across field studies in East Africa, an over-yield effect of Minjingu PR relative to TSP at equivalent $P$ rates is generally observed by year 3 (104\%) and has been attributable in part to its greater nutrient cation content (Szilas et al. 2007a). In addition to promoting reductions in exchangeable acidity, $\mathrm{Ca}$ additions via PR represent a significant input to weathered soils (Khasawneh and Doll 1979), which are generally Ca deficient (Njoku et al. 1987; Sale and Mokwunye 1993; Vitousek et al. 2010). Given that $\mathrm{Ca}$ may be an overlooked nutrient limitation in western Kenya (Kihara and Njoroge 2013), Minjingu PR offers additional non-P benefits to farmers in this region.

\section{Conclusion}

P fertilization of an acid, weathered soil in western Kenya for 13 cropping seasons produced changes in indicators of biological P cycling depending on the form of fertilizer, Minjingu phosphate rock (PR) or triple super phosphatase (TSP). At equal, recommended application rates $\left(50 \mathrm{~kg} \mathrm{P}^{-1}\right.$ season $^{-1}$ ), labile $\mathrm{P}$ was greater under Minjingu PR additions, whereas the less available $\mathrm{Fe}$ - and $\mathrm{Al}$-associated pool was greater with additions of the more soluble $\mathrm{P}$ form of TSP. Minjingu PR yielded $299 \%$ greater $\mathrm{P}_{\text {mic }}$ compared to TSP, and elevated acid phosphomonoesterase activity by $39 \%$. The liming effect and lower P solubility of Minjingu PR likely account for its enhancement of microbial and enzymatic components of $\mathrm{P}$ cycling compared to TSP. Compared to no $\mathrm{P}$ fertilization, $\mathrm{P}$ inputs increased $\mathrm{P}_{\text {mic }}$ and acid phosphomonoesterase activity, despite higher labile $\mathrm{P}$ and lower organic $\mathrm{P}$. This study identifies (1) improvements in plant-available $\mathrm{P}$ concurrent with elevated indicators of $\mathrm{P}$ cycling under $\mathrm{P}$ fertilization relative to no $\mathrm{P}$ inputs, (2) the potential of $\mathrm{P}$ fertilizer form to alter microbial and enzymatic drivers of soil $\mathrm{P}$ in the long-term, with (3) enhancement of biological cycling of $\mathrm{P}$ with P fertilization using Minjingu PR relative to TSP at recommended rates in weathered soils in western Kenya.

Acknowledgements We thank William Ogada for allowing this trial to be on his farm. We also thank CIAT staff, and specifically Evonne Oyugi, for providing field and technical support, and Dr. Nic Jelinski (University of Minnesota) for soil profiling. This trial was made possible with the financial support of Africa Students Research Network (AfNET), a US Borlaug Graduate Student Fellowship Global Food Security, and University of California-Davis Henry A. Jastro Award.

Open Access This article is distributed under the terms of the Creative Commons Attribution 4.0 International License (http:// creativecommons.org/licenses/by/4.0/), which permits unrestricted use, distribution, and reproduction in any medium, provided you give appropriate credit to the original author(s) and the source, provide a link to the Creative Commons license, and indicate if changes were made.

\section{References}

Achat DL, Morel C, Bakker MR, Augusto L, Pellerin S, Gallet-Budynek A, Gonzalez M (2010) Assessing turnover of microbial biomass phosphorus: combination of an isotopic dilution method with a mass balance model. Soil Biol Biochem 42:2231-2240. doi:10.1016/j. soilbio.2010.08.023

Acuña JJ, Durán P, Lagos LM, Ogram A, de la Luz Mora M, Jorquera MA (2016) Bacterial alkaline phosphomonoesterase in the rhizospheres of plants grown in Chilean extreme environments. Biol Fertil Soils 52:763-773. doi:10.1007/s00374-016-1113-9

Alvear M, Rosas A, Rouanet JL, Borie F (2005) Effects of three soil tillage systems on some biological activities in an Ultisol from southern Chile. Soil Tillage Res 82:195-202. doi:10.1016/j.still. 2004.06.002

Ayaga G, Todd A, Brookes PC (2006) Enhanced biological cycling of phosphorus increases its availability to crops in low-input subSaharan farming systems. Soil Biol Biochem 38:81-90. doi:10. 1016/j.soilbio.2005.04.019

Beck MA, Sanchez PA (1994) Soil phosphorus fraction dynamics during 18 years of cultivation on a Typic Paleudult. Soil Sci Soc Am J 58: 1424-1143. doi:10.2136/sssaj1994.03615995005800050021x

Bossio DA, Girvan MS, Verchot L, Bullimore J, Borelli T, Albrecht A, Scow KM, Ball AS, Pretty JN, Osborn AM (2005) Soil microbial community response to land use change in an agricultural landscape of western Kenya. Microb Ecol 49:50-62. doi:10.1007/s00248-0030209-6 
Brookes PC, Powlson DS, Jenkinson DS (1982) Measurement of microbial biomass phosphorus in soil. Soil Biol Biochem 14:319-329. doi:10.1016/0038-0717(82)90001-3

Bünemann EK, Bossio DA, Smithson PC, Frossard E, Oberson A (2004a) Microbial community composition and substrate use in a highly weathered soil as affected by crop rotation and $\mathrm{P}$ fertilization. Soil Biol Biochem 36:889-901. doi:10.1016/j.soilbio.2004.02.002

Bünemann EK, Smithson PC, Jama B, Frossard E, Oberson A (2004b) Maize productivity and nutrient dynamics in maize-fallow rotations in western Kenya. Plant Soil 264:195-208. doi:10.1023/B:PLSO. 0000047749.43017.fd

Bünemann EK, Steinebrunner F, Smithson PC, Frossard E, Oberson A (2004c) Phosphorus dynamics in a highly weathered soil as revealed by isotopic labeling techniques. Soil Sci Soc Am J 68:1645-1655. doi:10.2136/sssaj2004.1645

Buresh RJ, Sanchez PA, Calhoun F, Hatfield J, Bigham JM, Krai DM, Viney MK (1997) Replenishing soil fertility in Africa. Soil Science Society of America Press, Madison

Chien SH (1977) Thermodynamic considerations on the solubility of phosphate rock. Soil Sci 123:117-121

Conte E, Anghinoni I, Rheinheimer D (2002) Phosphorus in the microbial biomass and acid phosphatase activity by phosphate application in soil under no-tillage system. Rev Bras Ciênc Solo 26:925-930

Costa ARD, Sato JH, Ramos MLG, Figueiredo CCD, Souza GPD, Rocha OC, Guerra AF (2013) Microbiological properties and oxidizable organic carbon fractions of an Oxisol under coffee with split phosphorus applications and irrigation regimes. Rev Bras Ciênc Solo 37: $55-65$

Cui H, Zhou Y, Gu Z, Zhu H, Fu S, Yao Q (2015) The combined effects of cover crops and symbiotic microbes on phosphatase gene and organic phosphorus hydrolysis in subtropical orchard soils. Soil Biol Biochem 82:119-126. doi:10.1016/j.soilbio.2015.01.003

Culman SW, Sieglinde SS, Freeman MA, Schipanski ME, Beniston J, Lal R, Drinkwater LE, Franzluebbers AJ, Glover JD, Grandy AS, Lee J, Six J, Maul JE, Mirksy SB, Spargo JT, Wander MM (2012) Permanganate oxidizable carbon reflects a processed soil fraction that is sensitive to management. Soil Sci Soc Am J 76:494-504. doi:10.2136/sssaj2011.0286

Dieter D, Elsenbeer H, Turner BL (2010) Phosphorus fractionation in lowland tropical rainforest soils in central Panama. Catena 82:118 125. doi:10.1016/j.catena.2010.05.010

Geisseler D, Scow KM (2014) Long-term effects of mineral fertilizers on soil microorganisms - a review. Soil Biol Biochem 75:54-63. doi: 10.1016/j.soilbio.2014.03.023

Gichangi EM, Mnkeni PNS, Brookes PC (2010) Goat manure application improves phosphate fertilizer effectiveness through enhanced biological cycling of phosphorus. Soil Sci Plant Nutr 56:853-860. doi: 10.1111/j.1747-0765.2010.00515.x

Havlin J, Tisdale SL, Beaton JD, Nelson WL (2013) Soil fertility and fertilizers: an introduction to nutrient management. Pearson, New York

He LZ, Baligar CV, Martens CD, Ritchey DK (1997) Effect of phosphate rock, lime and cellulose on soil microbial biomass in acidic forest soil and its significance in carbon cycling. Biol Fertil Soils 24:329 334. doi: $10.1007 / \mathrm{s} 003740050252$

Hedley M, Stewart J, Chauhan B (1982) Changes in inorganic and organic soil phosphorus fractions induced by cultivation practices and by laboratory incubations. Soil Sci Soc Am J 46:970-976

Heuck C, Weig A, Spohn M (2015) Soil microbial biomass C:N:P stoichiometry and microbial use of organic phosphorus. Soil Biol Biochem 85:119-129. doi:10.1016/j.soilbio.2015.02.029

Hui D, Mayes MA, Wang G (2013) Kinetic parameters of phosphatase: a quantitative synthesis. Soil Biol Biochem 65:105-113. doi:10.1016/ j.soilbio.2013.05.017

Hurisso TT, Culman SW, Horwath WR, Wade J, Cass D, Beniston JW, Bowles TM, Grandy AS, Franzluebbers AJ, Schipanski ME, Lucas
ST, Ugarte CM (2016) Comparison of permanganate-oxidizable carbon and mineralizable carbon for assessment of organic matter stabilization and mineralization. Soil Sci Soc Am J 80:1352-1364. doi:10.2136/sssaj2016.04.0106

Jama B, Kiwia A (2009) Agronomic and financial benefits of phosphorus and nitrogen sources in western Kenya. Exp Agric 45:241-260. doi: 10.1017/S0014479709007510

Jama B, Van Straaten P (2006) Potential of east African phosphate rock deposits in integrated nutrient management strategies. Ana Acad Brasil Ciên 78:781-790

Jones D, Oburger E (2011) Solubilization of phosphorus by soil microorganisms. In: Bünemann E, Oberson A, Frossard E (eds) Phosphorus in action, vol 26. Soil biology. Springer, Berlin, pp 169-198. doi:10.1007/978-3-642-15271-9 7

KARI (1994) Fertilizer use recommendations. Kenya Agricultural Research Institute, Nairobi, pp 1-3

Khasawneh F, Doll E (1979) The use of phosphate rock for direct application to soils. Adv Agron 30:159-206

Kihara J, Njoroge S (2013) Phosphorus agronomic efficiency in maizebased cropping systems: a focus on western Kenya. Field Crop Res 150:1-8. doi:10.1016/j.fcr.2013.05.025

Kirkby CA, Richardson AE, Wade LJ, Batten GD, Blanchard C, Kirkegaard JA (2013) Carbon-nutrient stoichiometry to increase soil carbon sequestration. Soil Biol Biochem 60:77-86. doi:10.1016/j. soilbio.2013.01.011

Kisinyo P, Opala P, Palapala V, Gudu S, Othieno C, Ouma E (2015) Micro-dosing of lime, phosphorus and nitrogen fertilizers effect on maize performance on an acid soil in Kenya. Sust Agric Res 4:21

Kisinyo PO, Othieno CO, Gudu SO, Okalebo JR, Opala PA, Ng'Etich WK, Nyambati RO, Ouma EO, Agalo JJ, Kebeney SJ, Too EJ, Kisinyo JA, Opile WR (2014) Immediate and residual effects of lime and phosphorus fertilizer on soil acidity and maize production in western Kenya. Exp Agric 50:128-143. doi:10.1017/ S0014479713000318

Körschens M, Albert E, Armbruster M, Barkusky D, Baumecker M, Behle-Schalk L, Bischoff R, Čergan Z, Ellmer F, Herbst F, Hoffmann S, Hofmann B, Kismanyoky T, Kubat J, Kunzova E, Lopez-Fando C, Merbach I, Merbach W, Pardor MT, Rogasik J, Rühlmann J, Spiegel H, Schulz E, Tajnsek A, Toth Z, Wegener H, Zorn W (2013) Effect of mineral and organic fertilization on crop yield, nitrogen uptake, carbon and nitrogen balances, as well as soil organic carbon content and dynamics: results from 20 European long-term field experiments of the twenty-first century. Arch Agron Soil Sci 59:1017-1040. doi:10.1080/03650340.2012.704548

Ladha JK, Reddy CK, Padre AT, van Kessel C (2011) Role of nitrogen fertilization in sustaining organic matter in cultivated soils. J Environ Qual 40:1756-1766. doi:10.2134/jeq2011.0064

Lagos LM, Acuña JJ, Maruyama F, Ogram A, de la Luz Mora M, Jorquera MA (2016) Effect of phosphorus addition on total and alkaline phosphomonoesterase-harboring bacterial populations in ryegrass rhizosphere microsites. Biol Fertil Soils 52:1007-1019. doi:10.1007/s00374-016-1137-1

Loganathan P, Dayaratne PMN, Shanmuganathan RT (1982) Evaluation of the phosphorus status of some coconut-growing soils of Sri Lanka. J Agric Sci 99:25-33. doi:10.1017/S002185960005499X

Lucas ST, Weil RR (2012) Can a labile carbon test be used to predict crop responses to improve soil organic matter management? Agron J 104: 1160-1170. doi:10.2134/agronj2011.0415

Malik MA, Marschner P, Khan KS (2012) Addition of organic and inorganic $\mathrm{P}$ sources to soil - effects on P pools and microorganisms. Soil Biol Biochem 49:106-113. doi:10.1016/j.soilbio.2012.02.013

Marschner P (2008) The role of rhizosphere microorganisms in relation to P uptake by plants. In: White P, Hammond J (eds) The ecophysiology of plant-phosphorus interactions, vol 7. Plant ecophysiology. Springer, Dordrecht, pp 165-176. doi:10.1007/978-1-4020-843558 
Mukuralinda A, Tenywa JS, Verchot LV, Obua J (2011) Combined effect of organic and inorganic fertilizers on soil chemical and biological properties and maize yield in Rubona, southern Rwanda. In: Bationo A, Waswa B, Okeyo JM, Maina F, Kihara JM (eds) Innovations as key to the green revolution in Africa. Springer, Dordrecht, pp 729740. doi:10.1007/978-90-481-2543-2 74

Murphy J, Riley JP (1962) A modified single solution method for the determination of phosphate in natural waters. Anal Chim Acta 27: 31-36. doi:10.1016/S0003-2670(00)88444-5

Nandwa SM, Bekunda M (1998) Research on nutrient flows and balances in east and southern Africa: state-of-the-art. Agric Ecosyst Environ $71: 5-18$

Nannipieri P, Giagnoni L, Landi L, Renella G (2011) Role of phosphatase enzymes in soil. In: Bünemann EK, Oberson A, Frossard E (eds) Phosphorus in action. Springer, Dordrecht, pp 215-243

Ndungu-Magiroi K, Waswa B, Bationo A, Okalebo J, Othieno C, Herrmann L, Lesueur D (2015) Minjingu phosphate rock applications increase the population of phosphate solubilising microorganisms with a positive impact on crop yields in a Kenyan Ferralsol. Nutr Cycl Agroecosyst 102:91-99. doi:10.1007/ s10705-014-9661-6

Nekesa A, Okalebo J, Othieno C, Thuita M, Kipsat M, Bationo A, Sanginga N (2005) The potential of Minjingu phosphate rock from Tanzania as a liming material: effect on maize and bean intercrop on acid soils of western Kenya. Proc Afr Crop Sci Conf 7:1121-1128

Njoku BO, Enwezor WO, Onyenakwe BI (1987) Calcium deficiency identified as an important factor limiting maize growth in acid ultisols of eastern Nigeria. Fertil Res 14:113-123. doi:10.1007/ bf01066604

Nziguheba G, Palm CA, Buresh RJ, Smithson PC (1998) Soil phosphorus fractions and adsorption as affected by organic and inorganic sources. Plant Soil 198:159-168

Nziguheba G, Zingore S, Kihara J, Merckx R, Njoroge S, Otinga A, Vandamme E, Vanlauwe B (2016) Phosphorus in smallholder farming systems of sub-Saharan Africa: implications for agricultural intensification. Nutr Cycl Agroecosyst 104:321-340. doi:10.1007/ s10705-015-9729-y

Oberson A, Joner EJ (2005) Microbial turnover of phosphorus in soil. In: Turner BL, Frossard E, Baldwin DS (eds) Organic phosphorus in the environment. CABI, Wallingford, pp 133-164

Oberson A, Friesen DK, Rao IM, Smithson PC, Turner BL, Frossard E (2006) Improving phosphorus fertility in tropical soils through biological interventions. In: Uphoff N (ed) Biological approaches to sustainable soil systems. CRC Press, Boca Raton, pp 536-546

Oberson A, Pypers P, Bünemann E, Frossard E (2011) Management impacts on biological phosphorus cycling in cropped soils. In: Bünemann E, Oberson A, Frossard E (eds) Phosphorus in action, vol 26. Soil biology. Springer, Berlin, pp 431-458. doi:10.1007/ 978-3-642-15271-9_17

Oehl F, Oberson A, Probst M, Fliessbach A, Roth H-R, Frossard E (2001) Kinetics of microbial phosphorus uptake in cultivated soils. Biol Fertil Soils 34:31-41. doi:10.1007/s003740100362

Olander LP, Vitousek PM (2000) Regulation of soil phosphatase and chitinase activity by $\mathrm{N}$ and $\mathrm{P}$ availability. Biogeochemistry 49 : 175-190

Radersma S, Grierson P (2004) Phosphorus mobilization in agroforestry: organic anions, phosphatase activity and phosphorus fractions in the rhizosphere. Plant Soil 259:209-219. doi:10.1023/B:PLSO. 0000020970.40167 .40

Ragot SA, Kertesz MA, Mészáros É, Frossard E, Bünemann EK (2017) Soil phoD and phoX alkaline phosphatase gene diversity responds to multiple environmental factors. Appl Environ Microbiol 83: 7281-7289. doi:10.1093/femsec/fiw212

Redel YD, Rubio R, Rouanet JL, Borie F (2007) Phosphorus bioavailability affected by tillage and crop rotation on a Chilean volcanic derived Ultisol. Geoderma 139:388-396. doi:10.1016/j.geoderma. 2007.02.018

Renella G, Landi L, Ascher J, Ceccherini MT, Pietramellara G, Nannipieri P (2006) Phosphomonoesterase production and persistence and composition of bacterial communities during plant material decomposition in soils with different $\mathrm{pH}$ values. Soil Biol Biochem 38:795-802. doi:10.1016/j.soilbio.2005.07.005

Rivaie AA, Loganathan P, Graham JD, Tillman RW, Payn TW (2008) Effect of phosphate rock and triple superphosphate on soil phosphorus fractions and their plant-availability and downward movement in two volcanic ash soils under Pinus radiata plantations in New Zealand. Nutr Cycl Agroecosyst 82:75-88. doi:10.1007/s10705008-9170-6

Rowland AP, Haygarth PM (1997) Determination of total dissolved phosphorus in soil solutions. J Environ Qual 26:410-415. doi:10.2134/ jeq1997.00472425002600020011x

Sale PWG, Mokwunye AU (1993) Use of phosphate rocks in the tropics. Fertil Res 35:33-45. doi:10.1007/BF00750218

Sanchez PA, Shepherd KD, Soule MJ, Place FM, Buresh RJ, Izac AMN, Mokwunye AU, Kwesiga FR, Ndiritu CG, Woomer PL (1997) Soil fertility replenishment in Africa: an investment in natural resource capital. In: Buresh RJ, Sanchez PA, Calhoun F (eds) Replenishing soil fertility in Africa. Soil Science Society of America Press, Madison, pp 1-46

Savini I, Smithson PC, Karanja NK (2006) Effects of added biomass, soil $\mathrm{pH}$ and calcium on the solubility of Minjingu phosphate rock in a Kenyan Oxisol. Arch Agron Soil Sci 52:19-36. doi:10.1080/ 03650340500471922

Savini I, Kihara J, Koala S, Mukalama J, Waswa B, Bationo A (2016) Long-term effects of TSP and Minjingu phosphate rock applications on yield response of maize and soybean in a humid tropical maizelegume cropping system. Nutr Cycl Agroecosyst 104:79-91. doi:10. 1007/s10705-016-9760-7

Sikora F (2002) Evaluating and quantifying the liming potential of phosphate rocks. Nutr Cycl Agroecosyst 63:59-67

Spohn M, Kuzyakov Y (2013a) Distribution of microbial- and rootderived phosphatase activities in the rhizosphere depending on $\mathrm{P}$ availability and $\mathrm{C}$ allocation - coupling soil zymography with $14 \mathrm{C}$ imaging. Soil Biol Biochem 67:106-113. doi:10.1016/j.soilbio. 2013.08.015

Spohn M, Kuzyakov Y (2013b) Phosphorus mineralization can be driven by microbial need for carbon. Soil Biol Biochem 61:69-75. doi:10. 1016/j.soilbio.2013.02.013

Szilas C, Semoka JMR, Borggaard OK (2007a) Can local Minjingu phosphate rock replace superphosphate on acid soils in Tanzania? Nutr Cycl Agroecosyst 77:257-268. doi:10.1007/s10705-006-9064-4

Szilas C, Semoka JMR, Borggaard OK (2007b) Establishment of an agronomic database for Minjingu phosphate rock and examples of its potential use. Nutr Cycl Agroecosyst 78:225-237. doi:10.1007/ s10705-006-9086-y

Tabatabai M (1994) Soil enzymes. In: Bottomley PS, Angle JS, Weaver RW (eds) Methods of soil analysis: part 2-microbiological and biochemical properties. Soil Science Society of America Press, Madison, pp 775-833

Tabatabai MA (2003) Soil enzymes. In: Encyclopedia of environmental microbiology. Wiley. doi:10.1002/0471263397.env211

Tian J, Wei K, Condron LM, Chen Z, Xu Z, Chen L (2016) Impact of land use and nutrient addition on phosphatase activities and their relationships with organic phosphorus turnover in semi-arid grassland soils. Biol Fertil Soils 52:675-683. doi:10.1007/s00374-016-1110-z

Tiessen H, Moir J (1993) Characterization of available P by sequential extraction soil sampling and methods of analysis. In: Carter MR, Gregorich EG (eds) Soil sampling and methods of analysis, Second edn. CRC Press, Boca Raton, pp 293-306

Tiessen H, Stewart JWB, Moir JO (1983) Changes in organic and inorganic phosphorus composition of two grassland soils and their 
particle size fractions during 60-90 years of cultivation. J Soil Sci 34:815-823. doi:10.1111/j.1365-2389.1983.tb01074.x

Turner BL, Haygarth PM (2005) Phosphatase activity in temperate pasture soils: potential regulation of labile organic phosphorus turnover by phosphodiesterase activity. Sci Total Environ 344:27-36. doi:10. 1016/j.scitotenv.2005.02.003

Turrión M-B, López O, Lafuente F, Mulas R, Ruipérez C, Puyo A (2007) Soil phosphorus forms as quality indicators of soils under different vegetation covers. Sci Total Environ 378:195-198. doi:10.1016/j. scitotenv.2007.01.037

Van Kauwenbergh SJ (1991) Overview of phosphate deposits in east and Southeast Africa. Fert Res 30:127-150. doi:10.1007/BF01048645

van Straaten P (2002) Rocks for crops: agrominerals of sub-Saharan Africa. International Center for Research in Agroforestry, Nairobi

Vance CP (2008) Plants without arbuscular mycorrhizae. In: White P, Hammond J (eds) The ecophysiology of plant-phosphorus interactions, vol 7. Plant ecophysiology. Springer, Dordrecht, pp 117-142. doi:10.1007/978-1-4020-8435-5 6
Vance CP, Uhde-Stone C, Allan DL (2003) Phosphorus acquisition and use: critical adaptations by plants for securing a nonrenewable resource. New Phytol 157:423-447

Verchot LV, Borelli T (2005) Application of para-nitrophenol (pNP) enzyme assays in degraded tropical soils. Soil Biol Biochem 37:625633. doi:10.1016/j.soilbio.2004.09.005

Vitousek PM, Porder S, Houlton BZ, Chadwick OA (2010) Terrestrial phosphorus limitation: mechanisms, implications, and nitrogenphosphorus interactions. Ecol Appl 20:5-15. doi:10.1890/08-0127.1

Weil RR, Islam KR, Stine MA, Gruver JB, Samson-Liebig SE (2003) Estimating active carbon for soil quality assessment: a simplified method for laboratory and field use. Am J Altern Agric 18:3-17. doi:10.1079/AJAA200228

Zoysa AKN, Loganathan P, Hedley MJ (2001) Comparison of the agronomic effectiveness of a phosphate rock and triple superphosphate as phosphate fertilisers for tea (Camellia Sinensis L.) on a strongly acidic Ultisol. Nutr Cycl Agroecosyst 59:95-105. doi:10.1023/a: 1017516713145 